\title{
Synthesis, crystal structure and spectroscopic characterization of a new organic bismuthate (III) $\left[\mathrm{C}_{9} \mathrm{H}_{28} \mathrm{~N}_{4}\right]\left[\mathrm{Bi}_{2} \mathrm{Cl}_{10}\right] \cdot \mathrm{H}_{2} \mathrm{O}$
}

\author{
Z. Aloui $^{\mathrm{a}, \star}$, S. Abid $^{\mathrm{a}}$, E. Jeanneau ${ }^{\mathrm{b}}$, M. Rzaigui ${ }^{\mathrm{a}}$ and C. Ben Nasr ${ }^{\mathrm{a}}$
}

${ }^{a}$ Laboratoire de Chimie des Matériaux, Faculté des Sciences de Bizerte

7021 Zarzouna, Bizerte TUNISIE

E-mail address: Aloui_zouhaier@yahoo.fr; Sonia.abid@fsb.rnu.tn; Mohamed.rzaigui@fsb.rnu.tn; Cherif.bennasr@fsb.rnu.tn

${ }^{\mathrm{b}}$ Centre de Diffractométrie Henri Longchambon, Université Claude Bernard Lyon1,

5, rue de La Doua, 69100 Villeurbanne, France.

E-mail adress: Erwann.jeanneau@univ-lyon1.fr

\section{ABSTRACT}

The chemical preparation, crystal structure and spectroscopic characterization of $\left[\mathrm{C}_{9} \mathrm{H}_{28} \mathrm{~N}_{4}\right]\left[\mathrm{Bi}_{2} \mathrm{Cl}_{10}\right] . \mathrm{H}_{2} \mathrm{O}$ have been reported. This compound crystallizes in the monoclinic system in space group P21/c and cell parameters $a=12.2385$ (6), $b=17.3062(7), c=13.0772(6) \AA, \beta=104.475(5)^{\circ}, Z=4$ and $V=2681.9$ (2) $\AA^{3}$. Its crystal structure has been determined and refined to $R=0.049$, using 5848 independent reflections. The atomic arrangement can be described by an alternation of organic and inorganic layers. The inorganic layer built up of $\left[\mathrm{Bi}_{2} \mathrm{Cl}_{10}\right]^{4-}$ bioctahedra arranged in sandwich between the organic layer. The organic groups are interconnected by the water molecules through $\mathrm{N}-\mathrm{H}$... O $(\mathrm{W}) \mathrm{hydrogen}$ bonds to form infinite zig-zag chains spreading along the b-axis. These Chains are themselves interconnected by means of the $\mathrm{N}-\mathrm{H} \ldots \mathrm{Cl}$ hydrogen bonds originating from $\left[\mathrm{Bi}_{2} \mathrm{Cl}_{10}\right]^{4-}$ anions, to form a three-dimensional network. Intermolecular $\mathrm{Cl}$... $\mathrm{Cl}$ interactions between adjacent dimeric $\left[\mathrm{Bi}_{2} \mathrm{Cl}_{10}\right]^{4-}$ anions have been observed. The compound was also characterized by FT-IR and Raman spectrscopies.

\section{Keywords}

Organic-inorganic hybrid material; Halogenobismuthates (III); Crystal structure; X-ray diffraction; IR spectroscopy; Raman spectroscopy.

* Corresponding author: Zouhaier Aloui

Tel: +21697378588, fax +21672590566

E-mail address: Aloui_zouhaier@yahoo.fr

Address: Département de Chimie Faculté des Sciences de Bizerte, Zarzouna 7021 Tunisie.

\section{Academic Discipline And Sub-Disciplines}

Chemistry

\section{SUBJECT CLASSIFICATION}

Inorganic chemsitry

\section{TYPE (METHOD/APPROACH)}

\section{Council for Innovative Research}

Peer Review Research Publishing System

Journal: Journal of Advances in Chemistry

Vol. 9, No. 2

editorjaconline@gmail.com

www.cirworld.org/journals 


\section{INTRODUCTION}

Recently, many research activities into the field of organic-inorganic hybrid materials based on metal-halide compounds have attracted much interest. The interest in this hybrid materials stems from the benefits introduced by the inclusion of both organic and inorganic components into the product [1]. To date, the numerous metal-halide compounds involving $\mathrm{Sn}(\mathrm{II}), \mathrm{Pb}(\mathrm{II}), \mathrm{Sb}(\mathrm{III})$ and $\mathrm{Bi}(\mathrm{III})$ and various organic amines evoke much attention. The anionic metal-halide species has been observed to range in dimensionality from two-dimensional (2D) or one dimensional (1D) polymeric anions to discrete anions of various sizes.

A special attention has been focused on the alkylammonium halogenoantimonates(III) and bismuthates(III) because of their ferroelectic and ferroelastic properties [2, 3]. Moreover, the halogenobismuthates(III) complex salts have been studied intensively over the last decades. The X-ray structural studies of these compounds show that most of them are constituted by polynuclear anions with different polymerization geometries where the basic $\mathrm{MX}_{6}$ octahedra share corners, edges and faces [4-10]. The crystal packing of the title materials are mainly influenced by $\mathrm{N}-\mathrm{H}$...X hydrogen bonds. These interactions between cations and anions should play a relevant contribution to the formation of a particular type of complex salts.

With the aim of clarifying this aspect, we have considered the N,N'-Bis(3-aminiopropyl)-1,3-propane diaminium tetracation, which is able to form hydrogen bonding interactions. No halogenobismuthates(III) complex salts containing this cation have been studied until now. In this paper the results of the studies of the crystal structure and vibrational properties of $\left[\mathrm{C}_{9} \mathrm{H}_{28} \mathrm{~N}_{4}\right]\left[\mathrm{Bi}_{2} \mathrm{Cl}_{10}\right] . \mathrm{H}_{2} \mathrm{O}$ are described.

\section{Experimental section}

\section{1. General}

The infrared spectrum was recorded in the range $4000-400 \mathrm{~cm}^{-1}$ with a "Perkin-Elmer FTIR" spectrophotometer 1000 using a sample dispersed in spectroscopically pure $\mathrm{KBr}$ pressed into a pellet.

The Raman spectrum was recorded at room temperature using a Raman microprobe combined with a Dilor $X Y$ spectrometer, with the $514.5 \mathrm{~nm}$ radiation from an argon ion laser as the excitation beam. A microscope allowed selection of a region of good optical quality in the crystalline sample.

\section{2. Synthesis}

The $\left[\mathrm{C}_{9} \mathrm{H}_{28} \mathrm{~N}_{4}\right]\left[\mathrm{Bi}_{2} \mathrm{Cl}_{10}\right] \cdot \mathrm{H}_{2} \mathrm{O}$ crystals was obtained by dissolving a stoichiometric mixture of $\mathrm{Bi}\left(\mathrm{NO}_{3}\right)_{3} \cdot 5 \mathrm{H}_{2} \mathrm{O}$ and N,N'-Bis(3aminopropyl)-1,3-propane diamine in $\mathrm{HCl}(6 \mathrm{M})$ solution This reaction occurred in the presence of ethanol $(20 \mathrm{~mL})$. The resulting aqueous solution was stirred for $30 \mathrm{~min}$ and then kept for crystallization at room temperature. After several days of slow evaporation, colorless parallelepipedic monocrystals were formed in the solution. These crystals are stable in normal condition of temperature and hygrometry. A Suitable crystal was selected and mounted on a Gemini kappageometry diffractometer (Agilent Technologies UK Ltd) equipped with an Atlas CCD detector and using Mo radiation ( $\lambda=$ $0.71073 \AA$ A). Intensities were collected at $150 \mathrm{~K}$ by means of the CrysalisPro software [11]. Reflection indexing, unit-cell parameters refinement, Lorentz-polarization correction, peak integration and background determination were carried out with the CrysalisPro software [11]. An analytical absorption correction was applied using the modeled faces of the crystal [12]. The structure was solved by direct methods with SIR97 [13] and the least-square refinement on $\mathrm{F}^{2}$ was achieved with the CRYSTALS software [14]

All non-hydrogen atoms were refined anisotropically. The hydrogen atoms were all located in a difference map, but those attached to carbon atoms were repositioned geometrically. The $\mathrm{H}$ atoms were initially refined with soft restraints on the bond lengths and angles to regularize their geometry $(\mathrm{C}-\mathrm{H}$ in the range $0.93-0.98, \mathrm{~N}-\mathrm{H}$ in the range $0.86-0.89$ and $\mathrm{O}-\mathrm{H}=$ $0.82 \AA$ ) and $U_{\text {iso }}(H)$ (in the range 1.2-1.5 times $U_{\text {eq }}$ of the parent atom), after which the positions were refined with riding constraints. Structure representations were made with Diamond software [15]. Crystal data and refinement parameters are gathered in Table 1. Crystallographic data (CIF) for the structure reported in this paper have been deposited in the Cambridge Crystallographic Data Centre as supplementary materials, CCDC No 965915. Copies of the data can be obtained, free of charge, on application to the CCDC, 12 Union Road, Cambridge, CB2 1EZ, UK (fax: +44 (1223) 336-033; e-mail: deposit@ccdc.cam.ac.uk). 
Table 1. Experimental details of $\left[\mathrm{C}_{9} \mathrm{H}_{28} \mathrm{~N}_{4}\right]\left[\mathrm{Bi}_{2} \mathrm{Cl}_{10}\right] \cdot \mathrm{H}_{2} \mathrm{O}$.

\begin{tabular}{|c|c|}
\hline Empirical formula & $\mathrm{C}_{9} \mathrm{H}_{30} \mathrm{Bi}_{2} \mathrm{Cl}_{10} \mathrm{~N}_{4} \mathrm{O}$ \\
\hline Formula weight & $982.85 \mathrm{~g} \cdot \mathrm{mol}^{-1}$ \\
\hline Crystal system & Monoclinic \\
\hline Space group & $\mathrm{P} 21 / \mathrm{c}$ \\
\hline Temperature & $150 \mathrm{~K}$ \\
\hline \multicolumn{2}{|l|}{ Unit cell dimensions } \\
\hline$a, b, c(\AA)$ & $12.2385(6), 17.3062(7), 13.0772(6)$ \\
\hline$\beta\left(\left(^{\circ}\right)\right.$ & $104.475(5)$ \\
\hline$V\left(\AA^{3}\right)$ & $2681.9(2)$ \\
\hline Z & 4 \\
\hline Radiation type & $\operatorname{Mo~Ka}(\lambda=0.71073 \AA)$ \\
\hline$\mu$ & $14.11 \mathrm{~mm}$ \\
\hline Crystal dimensions (mm) & $0.44 \times 0.21 \times 0.16$ \\
\hline Diffractometer & $\begin{array}{l}\text { Xcalibur, Atlas, Gemini ultra } \\
\text { diffractometer }\end{array}$ \\
\hline Absorption correction & Analytical \\
\hline $\mathrm{T}_{\min } / \mathrm{T}_{\max }$ & $0.025 / 0.219$ \\
\hline Measured reflections & 37451 \\
\hline Independent reflections & 6899 \\
\hline Observed reflections with $\mathrm{I}>2 \sigma(\mathrm{I})$ & 5848 \\
\hline $\mathrm{R}_{\text {int }}$ & 0.083 \\
\hline Data/restraints/parameters & $6899 / 0 /$ \\
\hline Final $R$ indices $[I>2 \sigma(I)]$ & $R=0.0$ \\
\hline Goodness-of-fit on $\mathrm{F}^{2}, \mathrm{~S}$ & 1.00 \\
\hline$\Delta \rho_{\max }, \Delta \rho_{\min }\left(\mathrm{e} \AA^{-3}\right)$ & $4.29,-2$. \\
\hline
\end{tabular}

\section{Results and discussion}

\section{2. Crystal structure description}

The crystal structure of $\left[\mathrm{C}_{9} \mathrm{H}_{28} \mathrm{~N}_{4}\right]\left[\mathrm{Bi}_{2} \mathrm{Cl}_{10}\right] \cdot \mathrm{H}_{2} \mathrm{O}$ was determined at $150 \mathrm{~K}$. It is built up of discrete binuclear decachlorodibismathates(III) anions, N,N'-Bis(3-aminiopropyl)-1,3-propane diaminium tetracations and water molecules. The view of independent part and numbering scheme are presented in Figure1. 


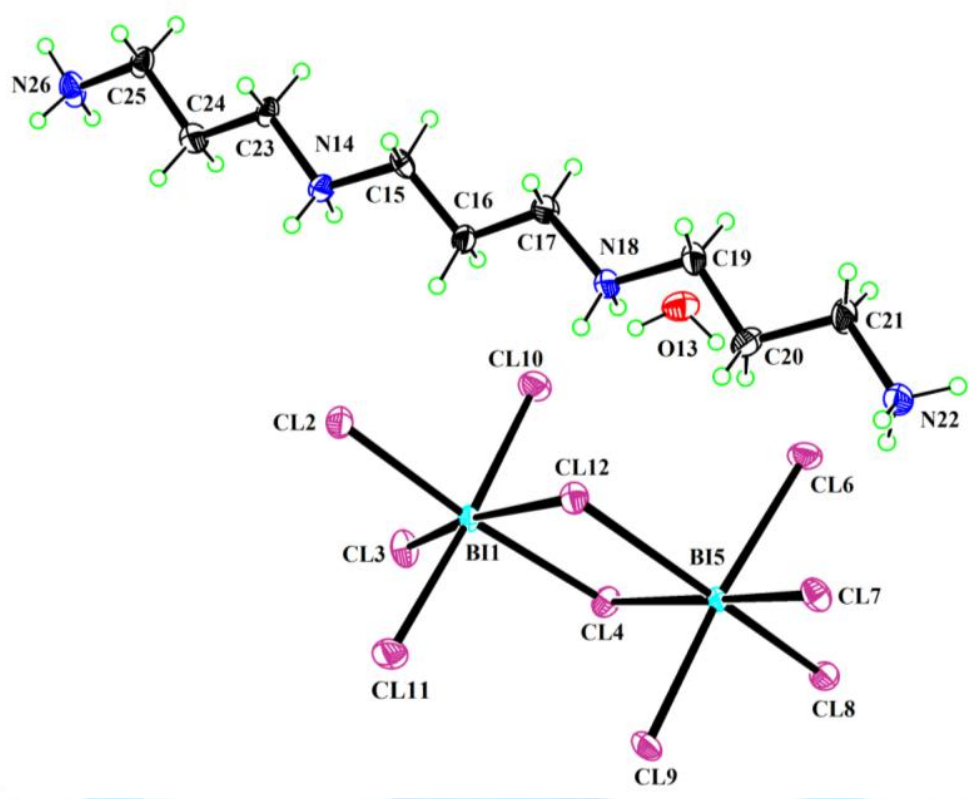

Fig 1. Asymmetric unit of $\left[\mathrm{C}_{9} \mathrm{H}_{28} \mathrm{~N}_{4}\right]\left[\mathrm{Bi}_{2} \mathrm{Cl}_{10}\right] \cdot \mathrm{H}_{2} \mathrm{O}$ with the atom numbering scheme and thermal ellipsoids at $50 \%$ probability and except for $\mathrm{H}$-atoms, which are represented by spheres of arbitrary radii.

The atomic arrangement can be described by a layer parallel to the $(b, c)$ plane of $\left[\mathrm{Bi}_{2} \mathrm{Cl}_{10}\right]^{4-}$ bioctahedra alternated with plane of the $\left[\mathrm{C}_{9} \mathrm{H}_{28} \mathrm{~N}_{4}\right]^{4+}$ tetracations. Anions, cations and water molecules are linked by a network of $\mathrm{N}-\mathrm{H} \ldots \mathrm{Cl}, \mathrm{O}-\mathrm{H} \ldots \mathrm{Cl}$, $\mathrm{C}-\mathrm{H} . . . \mathrm{Cl}$ and $\mathrm{N}-\mathrm{H} . . . \mathrm{Cl}$ hydrogen bonds into a three-dimensional framework. Figure 2 gives a projection, along the a direction, of this atomic arrangement.

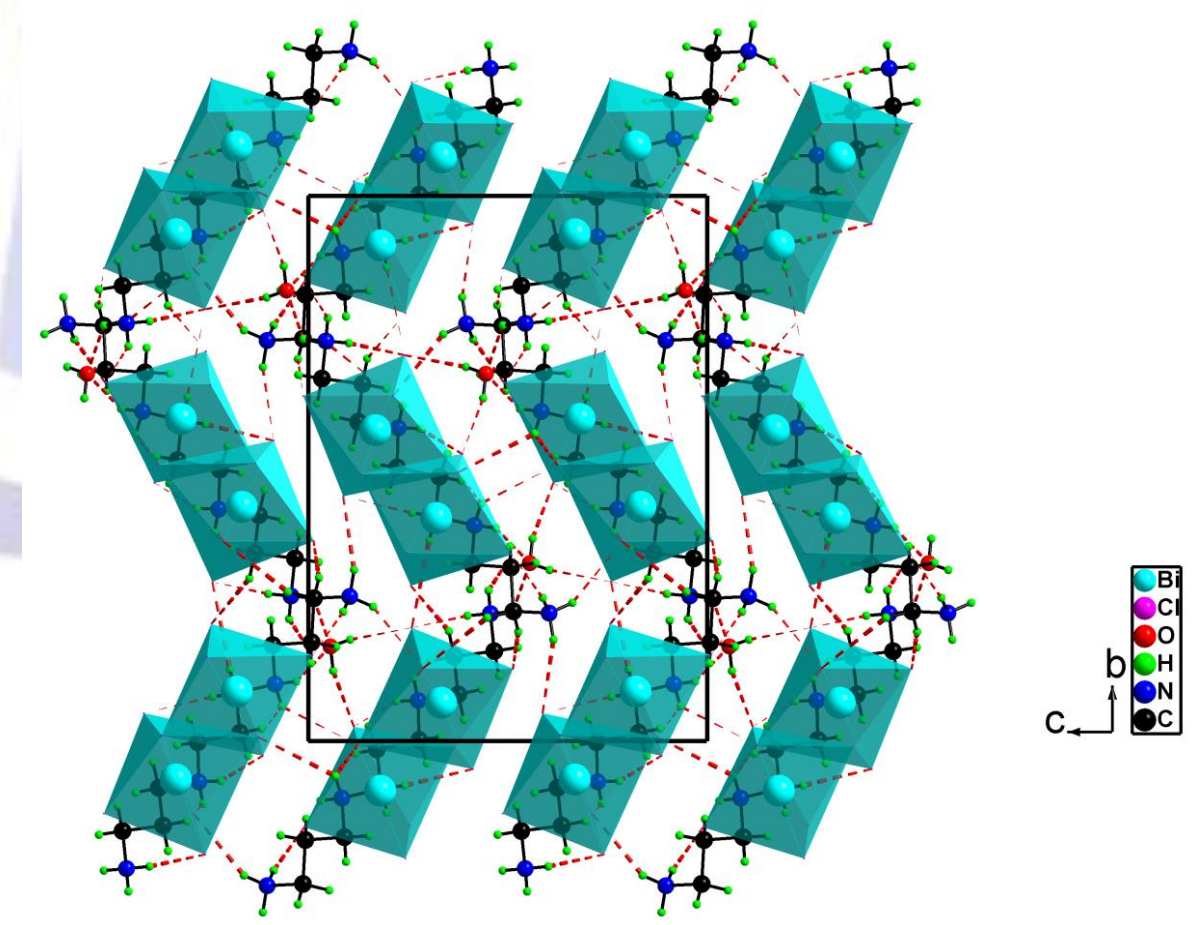

Fig 2. Projection of the crystal structure of $\left[\mathrm{C}_{9} \mathrm{H}_{28} \mathrm{~N}_{4}\right]\left[\mathrm{Bi}_{2} \mathrm{Cl}_{10}\right] \cdot \mathrm{H}_{2} \mathrm{O}$ along the a-axis. The dotted lines indicate hydrogen bonds.

Indeed, the $\left[\mathrm{C}_{9} \mathrm{H}_{28} \mathrm{~N}_{4}\right]^{4+}$ tetracations are interconnected by the water molecules through $\mathrm{N}-\mathrm{H}$... $\mathrm{O}(\mathrm{W})$ hydrogen bonds generated by the $\mathrm{NH}_{3}^{+}$and $\mathrm{NH}_{2}^{+}$ions, so that infinite $\left(\mathrm{C}_{9} \mathrm{H}_{28} \mathrm{~N}_{4} \mathrm{H}_{2} \mathrm{O}\right)_{n}{ }^{4 n+}$ zig-zag chains spreading along the b-axis were formed (Figure 3). 


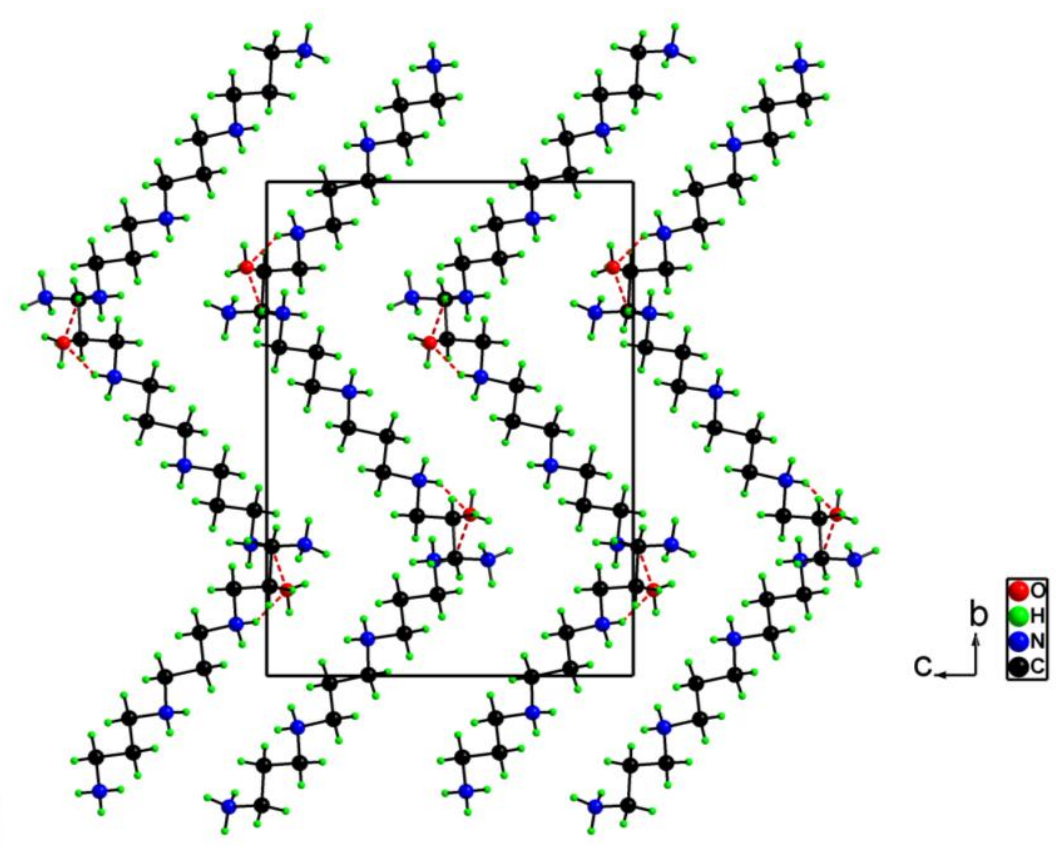

Fig 3. Projection of zig-zag chains in the crystal structure of $\left[\mathrm{C}_{9} \mathrm{H}_{28} \mathrm{~N}_{4}\right]\left[\mathrm{Bi}_{2} \mathrm{Cl}_{10}\right] . \mathrm{H}_{2} \mathrm{O}$ along the a-axis.

In these chains, pairs of symmetry-related organic cations are connected into centrosymmetric cavities via medium $\mathrm{N}$ $\mathrm{H}$... $(\mathrm{W})$ hydrogen bonds $[\mathrm{N} . . \mathrm{O}(\mathrm{W})=2.862(15) \AA]$ forming twenty-four-membered rings with an $\mathrm{R}_{4}{ }^{2}(24)$ motif $($ Figure 4$)$ [16].

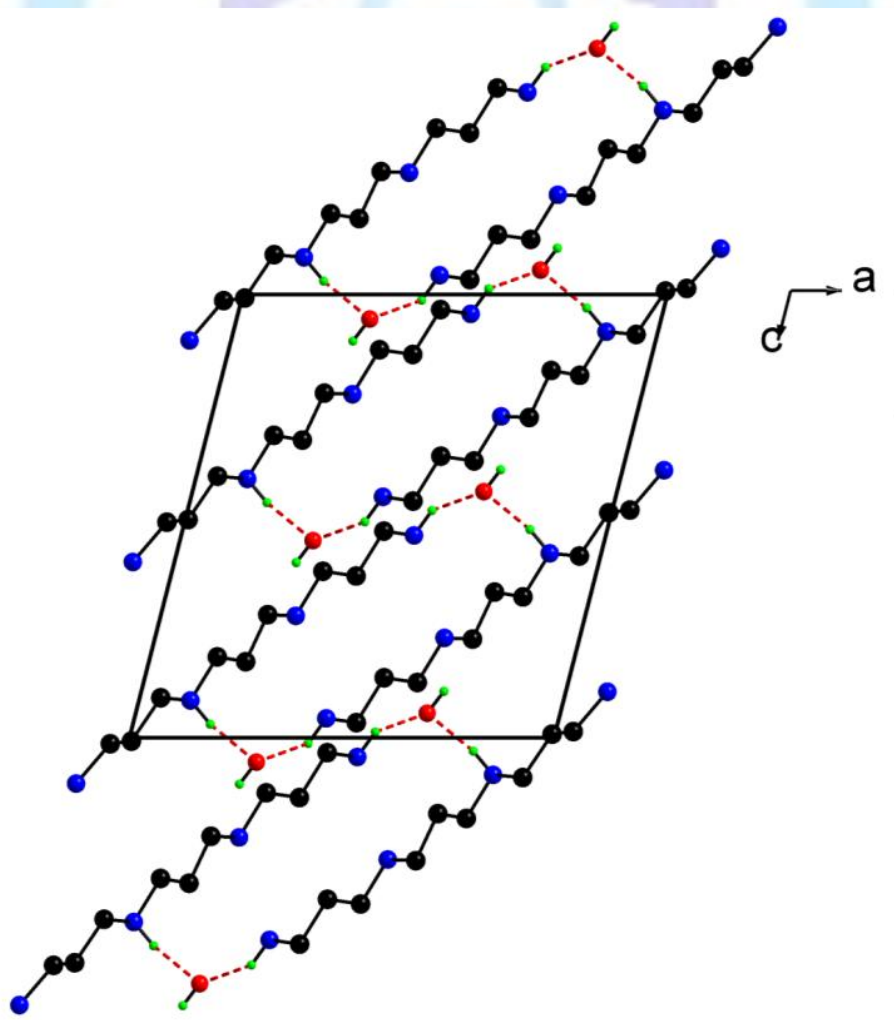

Fig 4. A view showing $\mathrm{R}_{4}{ }^{2}(24)$ motif built by $\mathrm{N}-\mathrm{H}$... O hydrogen bonds in $\left(\mathrm{C}_{9} \mathrm{H}_{28} \mathrm{~N}_{4} \mathrm{H}_{2} \mathrm{O}\right)_{n}{ }^{4 \mathrm{n}+}$ zig-zag chains. Hydrogen atoms are omitted for the clarity.

In the dimeric $\left[\mathrm{Bi}_{2} \mathrm{Cl}_{10}\right]^{4-}$ anion, two $\mathrm{Bi}^{3+}$ ions are bridged by two $\mathrm{Cl}$ - ions and each $\mathrm{Bi}^{3+}$ ion is additionally coordinated by four terminal $\mathrm{Cl}$ - ions forming a layer parallel to the $(b, c)$ plane. This dimeric bismuth-chloro-anion is a rare example of this kind. There are few reports of compounds that have described such an anion until now The Bi-Cl bonds lengths fall 
into two ranges: the longest bonds range from $2.769(3)$ to $2.993(3) \AA$ and that is a characteristic of the bridging chlorine atom and the shortest ones vary from 2.535(3) to 2.792(3) $\AA$ and these are typical of terminal chlorine (Table 2).

The $\mathrm{Cl}-\mathrm{Bi}-\mathrm{Cl}$ angles cis to each other are between 82.51 (8) to $97.04(9)^{\circ}$, while the $\mathrm{Cl}-\mathrm{Bi}-\mathrm{Cl}$ angles trans spread in the range $171.05(9)-174.98(9)^{\circ}$. These values are comparable to those reported to date [17, 18]. All these geometrical characteristics indicate that the two BiCl6 octahedra were distorted. This distorsion is correlated both to primary deformation resulting from the stereochemical activity of $\mathrm{Bi}$ lone electron pair [19] and to secondary deformation resulting from hydrogen bonds interactions [20]. The $\mathrm{BiCl}_{6}$ octahedra are united in pairs by bridging $\mathrm{Cl}$ atoms giving rise to binuclear $\left.\mathrm{Bi}_{2} \mathrm{Cl}_{10}\right]^{4-}$ anions. Adjacent $\left.\mathrm{Bi}_{2} \mathrm{Cl}_{10}\right]^{4-}$ bioctahedra in $\left[\mathrm{C}_{9} \mathrm{H}_{28} \mathrm{~N}_{4}\right]\left[\mathrm{Bi}_{2} \mathrm{Cl}_{10}\right] \cdot \mathrm{H}_{2} \mathrm{O}$ are displaced along the $b$ axis leading to a slight corrugation or up-down alternation of these bioctahedra progressing along the $\mathrm{c}$ axis within each layer . The $\mathrm{Bi}-\mathrm{Cl}-\mathrm{Bi}$ angles are $94.18(8)^{\circ}$ and $101.66(8)^{\circ}$ respectively, for $\mathrm{Bi}-\mathrm{Cl}(12)-\mathrm{Bi}$ and $\mathrm{Bi}-\mathrm{Cl}(4)-\mathrm{Bi}$ angles. The $\mathrm{Bi}-\mathrm{Bi}$ distance is $4.363(5) \AA$, and that is close to that observed in $\left[\mathrm{C}_{6} \mathrm{H}_{18} \mathrm{~N}_{2}\right]_{2}\left[\mathrm{Bi}_{2} \mathrm{Cl}_{10}\right] .3 \mathrm{H}_{2} \mathrm{O}$, which is equal to 4.3726 (3) $\AA$ [18]. Consequently, the $\left.\mathrm{Bi}_{2} \mathrm{Cl}_{10}\right]^{4-}$ bioctahedra is additionally distorted due to the formation of the $\mathrm{N}-\mathrm{H}$...Cl hydrogen bonds. It is worth-noticing that, as a result of bonding interactions, the $\left.\mathrm{Bi}_{2} \mathrm{Cl}_{10}\right]^{4-}$ anionic components were brought into close contact and, thus, $\mathrm{Cl} . . . \mathrm{Cl}$ interactions have been identified between chloride ligands of adjacent $\left.\mathrm{Bi}_{2} \mathrm{Cl}_{10}\right]^{4-}$ anions. Indeed, the $\mathrm{Cl}(10) \ldots \mathrm{Cl}(10)$ distance, of 3.557(3) $\AA$ is slightly less than the Van der Waal radii sum, indicating that the dimeric $\left.\mathrm{Bi}_{2} \mathrm{Cl}_{10}\right]^{4-}$ anions are in close contact. This $\mathrm{Cl}$... Cl interaction has been already observed in other structures where the $\mathrm{Cl}$...Cl distances vary from 3.538(1) Å to 3.813(1) Å [21].

Table 2 gives the principal geometrical features of the $\left[\mathrm{C}_{9} \mathrm{H}_{28} \mathrm{~N}_{4}\right]^{4+}$ tetracations. The $\mathrm{C}-\mathrm{N}, \mathrm{C}-\mathrm{C}$ bond lengths vary from $1.480(16)$ to $1.541(16) \AA$ and the $\mathrm{C}-\mathrm{C}-\mathrm{C}, \mathrm{C}-\mathrm{N}-\mathrm{C}$ and $\mathrm{N}-\mathrm{C}-\mathrm{C}$ angles spread from $108.2(9)$ to $114.3(9)^{\circ}$. These values are similar to those observed in other compounds[17].

Table 2. Selected geometric parameters $\left(\AA{ }^{\circ}\right)$ in $\left[\mathrm{C}_{9} \mathrm{H}_{28} \mathrm{~N}_{4}\right]\left[\mathrm{Bi}_{2} \mathrm{Cl}_{10}\right] \cdot \mathrm{H}_{2} \mathrm{O}$. Estimated standard deviations are given in parentheses.

\begin{tabular}{|c|c|c|c|}
\hline $\mathrm{Bi} 1-\mathrm{Cl} 2$ & $2.692(3)$ & N14-C15 & $1.493(14)$ \\
\hline $\mathrm{Bi} 1-\mathrm{Cl} 3$ & $2.535(3)$ & $\mathrm{N} 14-\mathrm{C} 23$ & $1.507(13)$ \\
\hline $\mathrm{Bi} 1-\mathrm{Cl} 4$ & 2.769 (3) & $\mathrm{C} 15-\mathrm{C} 16$ & $1.515(15)$ \\
\hline $\mathrm{Bi} 1-\mathrm{Cl} 10$ & $2.703(3)$ & $\mathrm{C} 16-\mathrm{C} 17$ & $1.504(15)$ \\
\hline $\mathrm{Bi} 1-\mathrm{Cl} 11$ & $2.658(3)$ & C17-N18 & $1.493(14)$ \\
\hline $\mathrm{Bi} 1-\mathrm{Cl} 12$ & $2.993(3)$ & N18-C19 & $1.510(15)$ \\
\hline $\mathrm{Bi} 5-\mathrm{Cl} 4$ & $2.858(3)$ & $\mathrm{C} 19-\mathrm{C} 20$ & $1.505(16)$ \\
\hline $\mathrm{Bi} 5-\mathrm{Cl} 6$ & $2.792(3)$ & $\mathrm{C} 20-\mathrm{C} 21$ & $1.523(16)$ \\
\hline $\mathrm{Bi} 5-\mathrm{Cl} 7$ & $2.613(3)$ & $\mathrm{C} 21-\mathrm{N} 22$ & $1.505(15)$ \\
\hline $\mathrm{Bi} 5-\mathrm{Cl} 8$ & $2.535(3)$ & $\mathrm{C} 23-\mathrm{C} 24$ & $1.541(16)$ \\
\hline $\mathrm{Bi} 5-\mathrm{Cl} 9$ & $2.625(3)$ & $\mathrm{C} 24-\mathrm{C} 25$ & $1.522(16)$ \\
\hline $\mathrm{Bi} 5-\mathrm{Cl} 12$ & $2.964(3)$ & $\mathrm{C} 25-\mathrm{N} 26$ & $1.480(16)$ \\
\hline $\mathrm{Cl} 2-\mathrm{Bi} 1-\mathrm{Cl} 3$ & $92.21(10)$ & $\mathrm{Cl} 4-\mathrm{Bi} 5-\mathrm{Cl} 9$ & $86.76(9)$ \\
\hline $\mathrm{Cl} 2-\mathrm{Bi} 1-\mathrm{Cl} 4$ & $174.98(9)$ & $\mathrm{Cl} 6-\mathrm{Bi} 5-\mathrm{Cl} 9$ & $174.63(10)$ \\
\hline $\mathrm{Cl} 3-\mathrm{Bi} 1-\mathrm{Cl} 4$ & $89.02(9)$ & $\mathrm{Cl} 7-\mathrm{Bi} 5-\mathrm{Cl} 9$ & $90.99(9)$ \\
\hline $\mathrm{Cl} 2-\mathrm{Bi} 1-\mathrm{Cl} 10$ & $88.36(10)$ & $\mathrm{Cl} 8-\mathrm{Bi} 5-\mathrm{Cl} 9$ & $91.75(9)$ \\
\hline $\mathrm{Cl} 3-\mathrm{Bi} 1-\mathrm{Cl} 10$ & $87.81(10)$ & $\mathrm{Cl} 4-\mathrm{Bi} 5-\mathrm{Cl} 12$ & $81.57(8)$ \\
\hline $\mathrm{Cl} 4-\mathrm{Bi} 1-\mathrm{Cl} 10$ & $86.82(9)$ & $\mathrm{Cl} 6-\mathrm{Bi5}-\mathrm{Cl} 12$ & $93.37(9)$ \\
\hline $\mathrm{Cl} 2-\mathrm{Bi} 1-\mathrm{Cl} 11$ & $89.39(10)$ & $\mathrm{Cl} 7-\mathrm{Bi5}-\mathrm{Cl} 12$ & $93.37(9)$ \\
\hline $\mathrm{Cl} 3-\mathrm{Bi} 1-\mathrm{Cl} 11$ & $87.36(10)$ & $\mathrm{Cl} 8-\mathrm{Bi} 5-\mathrm{Cl} 12$ & $171.05(9)$ \\
\hline $\mathrm{Cl} 4-\mathrm{Bi} 1-\mathrm{Cl} 11$ & $95.53(10)$ & $\mathrm{Cl} 9-\mathrm{Bi} 5-\mathrm{Cl} 12$ & $90.94(9)$ \\
\hline $\mathrm{Cl} 10-\mathrm{Bi} 1-\mathrm{Cl} 11$ & $174.59(10)$ & $\mathrm{Bi5}-\mathrm{Cl} 12-\mathrm{Bi} 1$ & $94.18(8)$ \\
\hline
\end{tabular}




\begin{tabular}{|c|c|c|c|}
\hline $\mathrm{Cl} 2-\mathrm{Bi} 1-\mathrm{Cl} 12$ & $96.34(8)$ & $\mathrm{C} 15-\mathrm{N} 14-\mathrm{C} 23$ & $111.7(9)$ \\
\hline $\mathrm{Cl} 3-\mathrm{Bi} 1-\mathrm{Cl} 12$ & $171.43(9)$ & $\mathrm{N} 14-\mathrm{C} 15-\mathrm{C} 16$ & $111.9(9)$ \\
\hline $\mathrm{Cl} 4-\mathrm{Bi} 1-\mathrm{Cl} 12$ & $82.51(8)$ & $\mathrm{C} 15-\mathrm{C} 16-\mathrm{C} 17$ & $108.2(9)$ \\
\hline $\mathrm{Cl} 10-\mathrm{Bi} 1-\mathrm{Cl} 12$ & $93.01(9)$ & $\mathrm{C} 16-\mathrm{C} 17-\mathrm{N} 18$ & $111.6(9)$ \\
\hline $\mathrm{Cl} 11-\mathrm{Bi} 1-\mathrm{Cl} 12$ & $92.13(9)$ & $\mathrm{C} 17-\mathrm{N} 18-\mathrm{C} 19$ & $114.3(9)$ \\
\hline $\mathrm{Bi} 1-\mathrm{Cl} 4-\mathrm{Bi} 5$ & $101.66(9)$ & $\mathrm{N} 18-\mathrm{C} 19-\mathrm{C} 20$ & $109.0(10)$ \\
\hline $\mathrm{Cl} 4-\mathrm{Bi} 5-\mathrm{Cl} 6$ & $97.04(9)$ & $\mathrm{C} 19-\mathrm{C} 20-\mathrm{C} 21$ & $108.7(10)$ \\
\hline $\mathrm{Cl} 4-\mathrm{Bi} 5-\mathrm{Cl} 7$ & $174.42(9)$ & $\mathrm{C} 20-\mathrm{C} 21-\mathrm{N} 22$ & $109.5(10)$ \\
\hline $\mathrm{Cl} 6-\mathrm{Bi} 5-\mathrm{Cl} 7$ & $85.56(10)$ & $\mathrm{N} 14-\mathrm{C} 23-\mathrm{C} 24$ & $110.3(9)$ \\
\hline $\mathrm{Cl} 4-\mathrm{Bi} 5-\mathrm{Cl} 8$ & $90.06(9)$ & $\mathrm{C} 23-\mathrm{C} 24-\mathrm{C} 25$ & $109.8(10)$ \\
\hline $\mathrm{Cl} 6-\mathrm{Bi} 5-\mathrm{Cl} 8$ & $84.47(9)$ & $\mathrm{C} 24-\mathrm{C} 25-\mathrm{N} 26$ & $109.1(10)$ \\
\hline $\mathrm{Cl} 7-\mathrm{Bi} 5-\mathrm{Cl} 8$ & $95.11(10)$ & & \\
\hline
\end{tabular}

The hydrogen bonds play an important role in establishing the structure, thus the presence of water molecules in the crystal cell interferes with the interaction of the cation nitrogen protons and the chlorines. The organic groups are linked to the $\left[\mathrm{Bi}_{2} \mathrm{Cl}_{10}\right]^{4-}$ anions via $\mathrm{C}-\mathrm{H} \ldots \mathrm{Cl}, \mathrm{N}-\mathrm{H} \ldots \mathrm{Cl}$ hydrogen bonds originating from $\mathrm{CH}_{2}, \mathrm{NH}_{3}{ }^{+}$and $\mathrm{NH}_{2}{ }^{+}$ions with $\mathrm{H}$...Cl distances ranging from 2.30 to $2.82 \AA$, and to the water molecules through $\mathrm{N}-\mathrm{H} \ldots \mathrm{O}(\mathrm{W})$ hydrogen bonds with $\mathrm{H}$... $\mathrm{O}(\mathrm{W})$ distances varying between 2.04 and $2.21 \AA$. The remaining hydrogen atoms of water molecules are connected to the chlorine atoms of $\left[\mathrm{Bi}_{2} \mathrm{Cl}_{10}\right]^{4-}$ anions with $\mathrm{H}$... Cl distances that are equal to $2.28 \AA$ and $2.31 \AA$ (Table 3 ). All these hydrogen bonds, electrostatic interactions and Van der Waals contacts have given rise to a three-dimensional network in the structure and added stability to this compound.

Table 3. Hydrogen-bonds geometry $\left(\stackrel{\AA}{\mathrm{A}}{ }^{\circ}\right)$ in $\left[\mathrm{C}_{9} \mathrm{H}_{28} \mathrm{~N}_{4}\right]\left[\mathrm{Bi}_{2} \mathrm{Cl}_{10}\right] \cdot \mathrm{H}_{2} \mathrm{O}$. Estimated standard deviations are given in parentheses.

\begin{tabular}{|c|c|c|c|c|}
\hline $\mathrm{D}-\mathrm{H} \cdots \mathrm{A}$ & $(\mathrm{D}-\mathrm{H})$ & $(H \cdots A)$ & $(D \cdots A)$ & $(\mathrm{DHA})$ \\
\hline $\mathrm{O} 13-\mathrm{H} 131 \cdots \mathrm{Cl} 6$ & 0.82 & 2.31 & $3.127(10)$ & 171 \\
\hline $\mathrm{O} 13-\mathrm{H} 132 \cdots \mathrm{Cl} 10$ & 0.82 & 2.28 & $3.062(11)$ & 160 \\
\hline $\mathrm{N} 14-\mathrm{H} 141 \cdots \mathrm{Cl} 10 \mathrm{ii}$ & 0.89 & 2.30 & $3.151(10)$ & 158 \\
\hline $\mathrm{N} 14-\mathrm{H} 142 \cdots \mathrm{Cl}$ 7iii & 0.89 & 2.87 & $3.522(10)$ & 132 \\
\hline $\mathrm{N} 18-\mathrm{H} 181 \cdots \mathrm{O} 13$ & 0.89 & 2.04 & $2.853(14)$ & 150 \\
\hline $\mathrm{N} 18-\mathrm{H} 182 \cdots \mathrm{Cl} 12$ & 0.89 & 2.72 & $3.335(11)$ & 127 \\
\hline $\mathrm{N} 18-\mathrm{H} 182 \cdots \mathrm{Cl} 12 \mathrm{iii}$ & 0.89 & 2.65 & $3.355(11)$ & 137 \\
\hline N22-H221‥Cl9iv & 0.89 & 2.41 & $3.194(11)$ & 148 \\
\hline N22-H222 ‥Cl2iii & 0.89 & 2.40 & $3.283(12)$ & 169 \\
\hline $\mathrm{N} 22-\mathrm{H} 223 \cdots \mathrm{Cl} 7$ & 0.89 & 2.53 & $3.255(11)$ & 139 \\
\hline N26-H261‥Cl6ii & 0.89 & 2.37 & $3.257(12)$ & 172 \\
\hline $\mathrm{N} 26-\mathrm{H} 262 \cdots \mathrm{O} 13 \mathrm{i}$ & 0.89 & 2.21 & $2.862(15)$ & 130 \\
\hline $\mathrm{N} 26-\mathrm{H} 263 \cdots \mathrm{Cl}^{\mathrm{v}}$ & 0.89 & 2.49 & $3.274(11)$ & 147 \\
\hline $\mathrm{C} 17-\mathrm{H} 171 \cdots \mathrm{Cl} 9^{\prime \prime \prime}$ & 0.98 & 2.74 & $3.710(12)$ & 174 \\
\hline $\mathrm{C} 21-\mathrm{H} 211 \cdots \mathrm{Cl} 8^{\mathrm{VI}}$ & 0.97 & 2.82 & $3.739(14)$ & 158 \\
\hline $\mathrm{C} 24-\mathrm{H} 241 \cdots \mathrm{Cl} 11^{v}$ & 0.97 & 2.82 & $3.719(14)$ & 153 \\
\hline
\end{tabular}

Symmetry codes: (i) $-x+1, y-1 / 2,-z+1 / 2$; (ii) $-x+1,-y+1,-z+1$; (iii) $-x,-y+1,-z+1$; (iv) $-x, y+1 / 2,-z+3 / 2$; (v) $x,-y+1 / 2, z-1 / 2 ;(v i) x,-y+3 / 2, z-1 / 2$. 


\section{3. IR spectroscopy}

The IR spectrum of the crystalline complex $\left[\mathrm{C}_{9} \mathrm{H}_{28} \mathrm{~N}_{4}\right]\left[\mathrm{Bi}_{2} \mathrm{Cl}_{10}\right] \cdot \mathrm{H}_{2} \mathrm{O}$ is shown in Figure 5 . The characteristic vibrational modes of the title compound can be compared to those of similar materials containing alkylammonium cation [22] . In the high-frequency region, the two bands at $3328-3203 \mathrm{~cm}^{-1}$ correspond to the vas $\left(\mathrm{NH}_{3}\right)$ asymmetric stretching modes and to the $v(\mathrm{O}-\mathrm{H})$ stretching vibration, while the two bands at 3143 and 3072 are assigned to $v \mathrm{~s}\left(\mathrm{NH}_{3}\right)$ asymmetric stretching modes. The shoulder set at $2930 \mathrm{~cm}^{-1}$ is attributed to the vas $\left(\mathrm{CH}_{2}\right)$ asymmetric stretching modes, while the weak peak situated at $2810 \mathrm{~cm}^{-1}$ corresponds to non-fundamental $\mathrm{NH}$ and $\mathrm{CH}$ stretching modes. Bands of weak intensities observed in the $2600-2400 \mathrm{~cm}^{-1}$ spectral region are assigned to combination and overtone bands involving probably the $\mathrm{NH}$ deformation modes and the $\mathrm{C}-\mathrm{NH}_{3}$ torsion modes around the $\mathrm{C}-\mathrm{N}$ bond [23]. The bands observed at 1600,1581 and 1473 $\mathrm{cm}^{-1}$ are assigned to the $\delta(\mathrm{OH})$ bending mode, the asymmetric $\delta a s\left(\mathrm{NH}_{3}\right)$ and $\delta a\left(\mathrm{NH}_{3}\right)$ symmetric bending modes, respectively.

The adjacent carbon atoms attached to the $\mathrm{CH}_{2}$ groups were also involved in the wagging, twisting and rocking modes of these groups. This has induced a coupling between the adjacent $\mathrm{CH}_{2}$ groups. Thus, the bands observed at (1434-1163 $\mathrm{cm}^{-1}$ ) are assigned to the waging modes, those observed at $\left(1273-1053 \mathrm{~cm}^{-1}\right)$ to the twisting modes and, finally, those observed at (1130-760 $\left.\mathrm{cm}^{-1}\right)$ to the rocking modes [24].

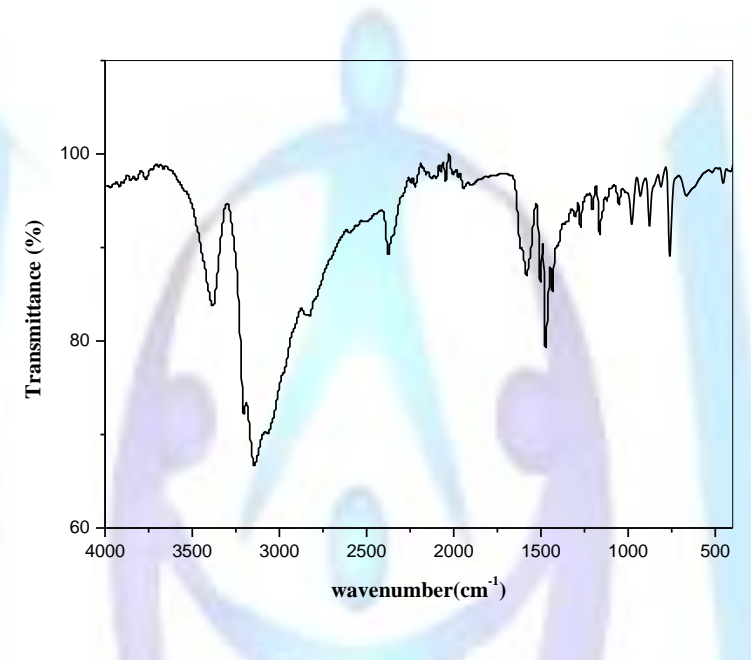

Fig 5. IR absorption spectrum of $\left[\mathrm{C}_{9} \mathrm{H}_{28} \mathrm{~N}_{4}\right]\left[\mathrm{Bi}_{2} \mathrm{Cl}_{10}\right] \cdot \mathrm{H}_{2} \mathrm{O}$.

\section{III.3. Raman Spectroscopy}

The Raman spectrum of $\left[\mathrm{C}_{9} \mathrm{H}_{28} \mathrm{~N}_{4}\right]\left[\mathrm{Bi}_{2} \mathrm{Cl}_{10}\right] \cdot \mathrm{H}_{2} \mathrm{O}$ was recorded in the external region of the anionic sublattice vibration 500 $100 \mathrm{~cm}-1$. The Raman bands of $\left[\mathrm{C}_{9} \mathrm{H}_{28} \mathrm{~N}_{4}\right]\left[\mathrm{Bi}_{2} \mathrm{Cl}_{10}\right] . \mathrm{H}_{2} \mathrm{O}$ observed in these Wavenumber regions are shown in Figure 6 . At room temperature, the crystallographic data indicate that the anionic sublattice of this hydrate compound is made of isolated $\left[\mathrm{Bi}_{2} \mathrm{Cl}_{10}\right]^{4-}$ dimers which are the association of two $\left[\mathrm{BiCl}_{6}\right]^{3-}$ distorted octahedrals sharing one edge. The longest $\mathrm{Bi}-$ $\mathrm{Cl}$ is characteristic of the bridging chlorine atoms, whereas the shortest ones correspond to the terminal chlorine atoms. Thus, in the Raman spectrum, of $\left[\mathrm{C}_{9} \mathrm{H}_{28} \mathrm{~N}_{4}\right]\left[\mathrm{Bi}_{2} \mathrm{Cl}_{10}\right] \cdot \mathrm{H}_{2} \mathrm{O}$, the strong band at $280 \mathrm{~cm}^{-1}$ was assigned to terminal $\mathrm{Bi}-\mathrm{Cl}$ stretching vibrations, the moderate band at 260 and very weak at $200 \mathrm{~cm}^{-1}$ were assigned to the bridging $\mathrm{Bi}-\mathrm{Cl}$ stretching vibration [23]. The bands corresponding to the deformation mode $\mathrm{Cl}-\mathrm{Bi}-\mathrm{Cl}$ appeared at 143 and $118 \mathrm{~cm}^{-1}$. Frequency for the bending modes occurred at $105 \mathrm{~cm}^{-1}$ [24]. 


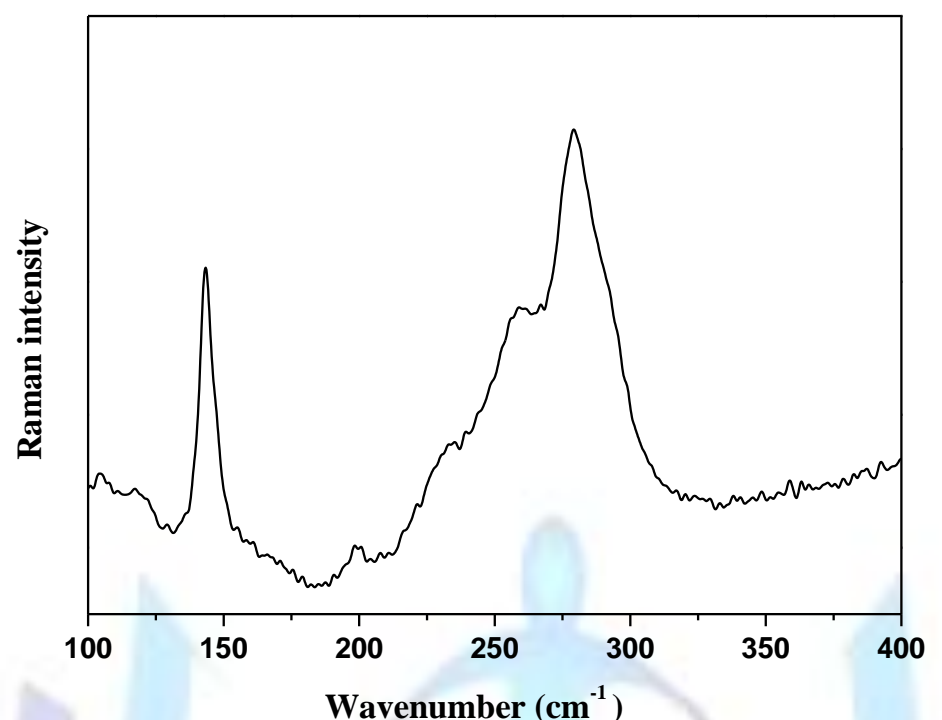

Fig 6. Raman spectrum of $\left[\mathrm{C}_{9} \mathrm{H}_{28} \mathrm{~N}_{4}\right]\left[\mathrm{Bi}_{2} \mathrm{Cl}_{10}\right] \cdot \mathrm{H}_{2} \mathrm{O}$.

\section{Conclusion}

The crystal packing of this hybrid compound shows moderate and weak interlocking between the inorganic and organic entities by multidirectional hydrogen-bonding network. The crystallographic studies has illustrated that $\left[\mathrm{C}_{9} \mathrm{H}_{28} \mathrm{~N}_{4}\right]\left[\mathrm{Bi}_{2} \mathrm{Cl}_{10}\right] . \mathrm{H}_{2} \mathrm{O}$ crystallizes in the centrosymmetric space groupe $\mathrm{P} 21 / \mathrm{c}$. Its crystal structure contains one protonated $\left[\mathrm{C}_{9} \mathrm{H}_{28} \mathrm{~N}_{4}\right]^{4+}$ tetracations, one water molecule and one dinuclear $\left[\mathrm{Bi}_{2} \mathrm{Cl}_{10}\right]^{4-}$ anion held together by $\mathrm{N}-\mathrm{H} \ldots \mathrm{Cl}, \mathrm{N}-$ $\mathrm{H} \ldots \mathrm{O}, \mathrm{O}-\mathrm{H} \ldots \mathrm{Cl}, \mathrm{C}-\mathrm{H} \ldots \mathrm{Cl}$ hydrogen bonds and electrostatic interactions which contribute to an extensive threedimensional network. Hydrogen bonds is one the versatile non covalent forces in supramolecular chemistry and crystal engineering. The vibrational properties of this compound were investigated by Raman and infrared spectroscopy.

\section{ACKNOWLEDGMENTS}

This work is supported by the Ministry of Higher Education and Scientific Research in Tunisia.

\section{REFERENCES}

[1] F. Neve, O. Francescangeli, A. Crispini, Inorg. Chem. Acta 338 (2002) 51-58.

[2] R. Jakubas, L. Sobczyk, Phase Transitions 20 (1990) 163-193.

[3] B. Kulicka, R. Jakubas, B. Bednarska-Bolek, G. Bator, Z. Ciunik, J. Mol. Struct 792 (2006) 151-156.

[4] F. Lazzarini, Acta Cryst. C41 (1985) 1617-1649.

[5] R. Blachnik, B. Jaschinski, H. Reuter, G. Z. Kauster, Kristallogr. 212 (1997) 874.

[6] A. Z. Lipka, Naturforsch Teil B38 (1983) 1615.

[7] J. Lefebvre, P. Carpentier, R. Jakubas, Acta Crystallogr. B47 (1991) 228-234.

[8] A. Z. Lipka, Anorg. Allg. Chem. 469 (1980) 229.

[9] B. Blazic, F. Lazzarini, Acta Crystallogr. C41 (1985) 1619-1621.

[10] H. Ishihara, S. Dou, A. Weiss, B. Bunsenges, Phys. Chem. 95 (1991) 659.

[11] CrysAlisPro, Agilent Technologies, Version 1.171.36.28 (release 01-02-2013) CrysAlis171 .NET) (compiled Feb1 2013, 16, 14, 44).

[12] R. C. Clark, J. S. Reid, Acta Crystallogr, A51 (1995) 887-897. 
[13] A. Altomare, M. C. Burla, M. Camalli, G. L. Cascarano, C. Giacovazzo, A. Guagliardi, A. G. G. Moliterni, G. Polidori, R. Spagna, J. Appl Crystallogr. 32 (1999) 115-119.

[14] P. W. Betteridge, J. R. Carruthers, R. I. Cooper, K. Prout, D. J. Watkin, J. Appl. Crystallogr. 36 (1998) 1487.

[15] K. Brandenburg, DIAMOND. Version 2.1. Crystal Impact GbR, Bonn, Germany, 1998.

[16] J. Bernstein, R. E. Davis, L. Shimoni, N. L. Chang, Angew. Chem. Int. Ed.34 (1995) 1555-1573.

[17] P. Ciapala, R. Jakuba, G. Bator, J. Zaleski, A. Pietrazko, M. Drozd, J. Baran. J. Phys. Condens. Matter. 9 (1997) 627-645.

[18] I. Turel, L. Goli, P. Bukovec, M. Gubina, J. Inorg. Biochem. 71 (1998) 53-60.

[19] S. Chaabouni, S. kamoun,J. Jaud, J. Chem. Crystallogr.28 (1998) 209-212.

[20] M. Khelifi, I. Mkaouar, F. Hlel, A. Ben Salah, R. Zouari. Ionics 16 (2010) 709-715.

[21] V. R. Hathwar, S. M. Roopan, R. Subashini, F. N. Khan, T. N. G. Row, T. N. G. J. Chem. Sci. 122 (2010) 677-685.

[22] M. Belhouchet, M. Bahri, J. M. Savariault, T. Mhiri, Spectrochim. Acta A 61 (2005) 387-393.

[23] G. Hertzberg, Infrared and Raman Spectra of Polyatomic Molecules, Van Nostrand, New york, 1966.

[24] Nakamoto, Infrared and Raman Spectra of Inorganic and Coordination Compounds, Wiley-Interscience, 1986.

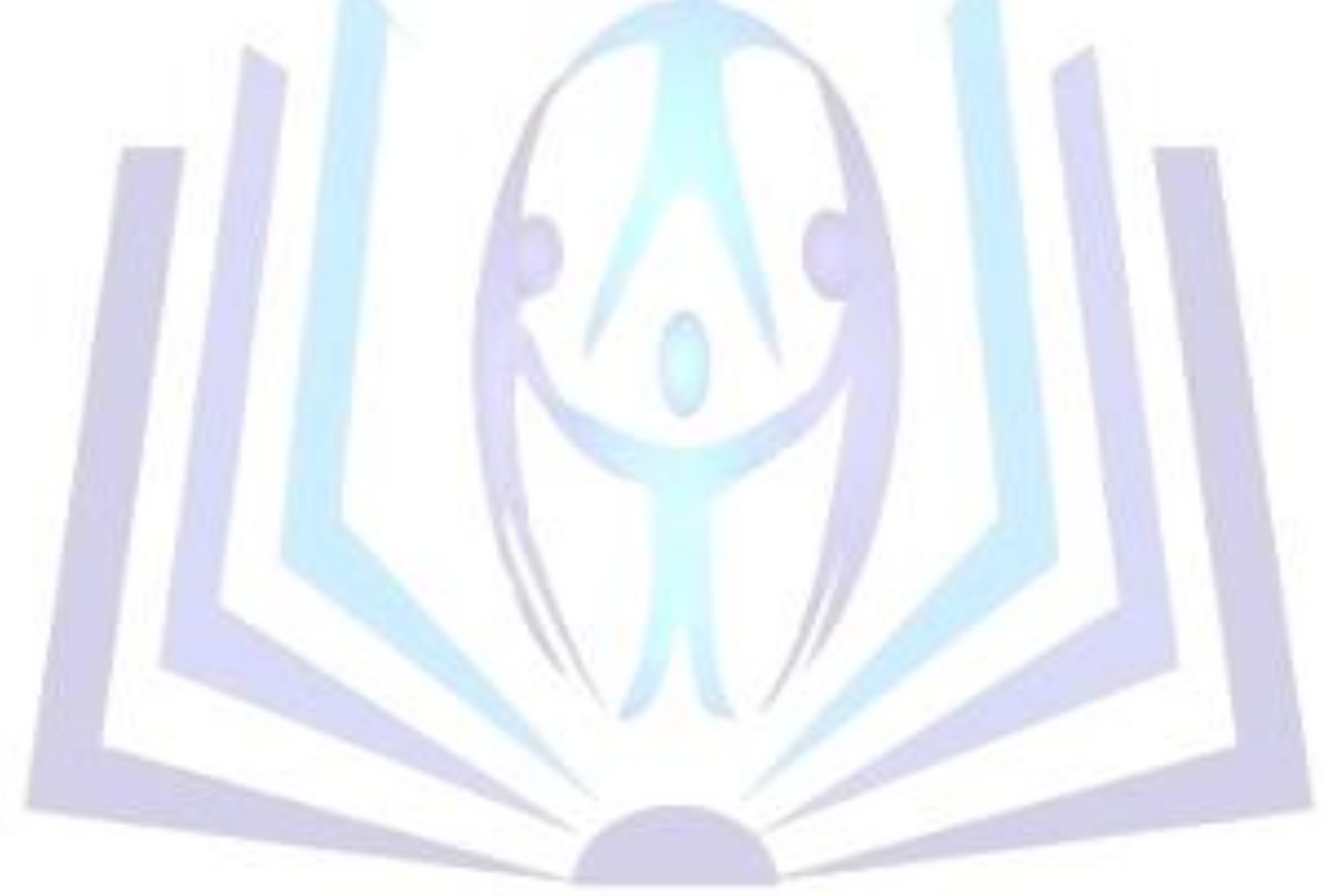

